1973

\title{
How the Government Breaks the Law (1973)
}

Jethro K. Lieberman

New York Law School, jethro.lieberman@nyls.edu

Follow this and additional works at: https://digitalcommons.nyls.edu/fac_books

\section{Recommended Citation}

Lieberman, Jethro K., "How the Government Breaks the Law (1973)" (1973). Books. 75.

https://digitalcommons.nyls.edu/fac_books/75

This Article is brought to you for free and open access by the Faculty Scholarship at DigitalCommons@NYLS. It has been accepted for inclusion in Books by an authorized administrator of DigitalCommons@NYLS. 
JETHRO K. LIEBERMAN

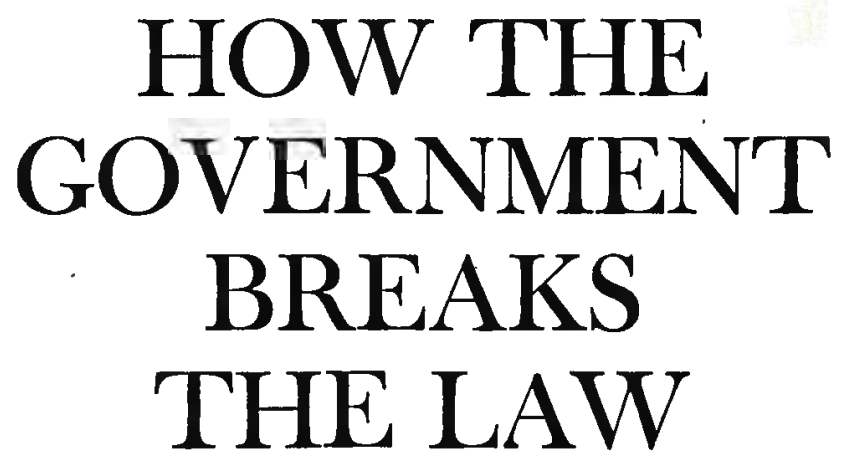

;

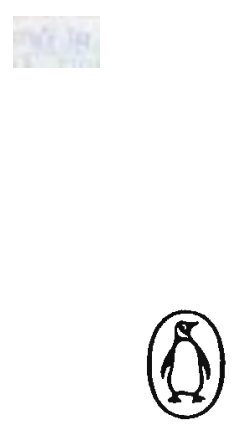

Penguin Books Inc

Baltimore - Maryland 


\section{For Susan, of course, and Jessica and Seth}

Penguin Books Inc 7110 Ambassador Road Baltimore, Maryland 21207, U.S.A.

First published by Stein and Day/Publishers/New York, 1972 Published in Penguin Books 1973

Copyright (C) Jethro K. Licberman, 1972, 1973

Printed in the United States of America by Kingsport Press, Inc, Kingsport, Tennessee

$$
\begin{aligned}
& K F \\
& 384 \\
& L 5 \\
& 1973 \\
& C .2
\end{aligned}
$$




\section{Acknowledgments}

MANY PEOPLE aided in the development of this book and I gratefully acknowledge their help. Sandor Frankel and Marc L. Fleischaker read the entire manuscript and made many valuable suggestions and corrections. Senator William Proxmire and his legislative assistant Thomas van der Voort helped me greatly in pursuing with the Comptroller General the issue of civilian control of the military. I recall with pleasure numerous enlightening conversations with John $\mathbf{H}$. Stassen (especially in connection with fund impounding and civilian control of the military) and with Salvatore A. Romano, Denis M. Neill, Joseph Sahid, James P. Mercurio, and Donald M. Barnes. Many of the attorneys for Lloyd Eldon Miller, Jr., provided details of that case. I am grateful to my father, J. Ben Lieberman, and to Jon M. Van Dyke, for discussions concerning scope and emphasis. Mary Solberg was a subtle and discerning editor, and Maureen McFeeley's cheerfulness in the face of my typing requests was awesome. Thanks are due also to many others, some in the Government, who would not care to be named, who have answered queries large and small.

Special thanks are due my wife, Susan E. V. Lieberman, for perceptive criticisms, bountiful all-purpose aid and comfort, and stoic patience at the newspaper clipping service that seemed to take over our home.

Washington, D.C., April, 1972 


\section{Contents}

Acknowledgments

Preface

1 A Healthy Contempt for the Law

2 Crimes Against the Individual

EMBARRASSING TRUTHS

The Case of A. Ernest Fitzgerald

The Case of Cora T. Walker

THE PROSECÜTOR COVERS UP

The Case of Lloyd Eldon Miller, Jr. 35

The Cases of Thomas J. Mooney and Warren K. Billings 48

Some Cases in Brief

HIS HONOR, THE JUDGE

Hon. Leonard P. Walsh

Minor Derelictions

Chief Judge Edward M. Curran

HOW TO GET A TAX EVADER

The Case of Reuben G. Lenske

Yankee Independence 
3 Crimes Affecting Groups

CIVILIAN DISSIDENTS

The Blunt End of the Law

The Disorderly House of Effete Intellectuals

Fomenting Unrest and the Frame-up

82

Guilty Because You Disagree

83

Domestic Subversives, We're Listening to You

MILITARY DISSIDENTS

93

DRAFTEES

102

SUSPECTS AND DEFENDANTS

104

Search and Seizure

105

Bail

110

The Third Degree

113

The Unlawful Arrest

PRISONERS

BLACKS

Murder and Other Harassments

Voting

Schools: Modern Techniques

Discrimination in Federal and State Contracting

Miscegenation

INDIANS

JUVENILES

144

THE POOR

ALIENS

4 Crimes Affecting Everyone

160

GIVILIAN CONTROL OF THE MILITARY

FUND IMPOUNDING: PARSIMONIOUS SPENDING OF THE PUBLIC MONIES

ABUSING THE TAXPAYER: PROFLIGATE SPENDING

OF THE PUBLIC MONIES

GAMPAIGN PRACTICES

LEGISLATIVE DISTRICTING: HOW LEGISLATURES BREAK THE LAW 
5 Crimes Affecting No One

THE UNLAWFUL APPOINTMENT OF MR. JUSTICE BLACK

DESECRATTNG THE FLAG

201

OTHER FOIBLES

203

6 Private Crimes of Government Officials

205

CONFLICTS OF INTEREST: THE LAW THAT NEVER WAS

205

PRESIDENT NIXON TAKES A BRIBE

208

CORRUPTION

213

7 The Government Responds or How to Spot a Lawbreaker

219

DENIAL

220

EVASION

223

PROMISING ACTION OR INVESTIGATION

225

NECESSITY

225

ACCUSING THE ACCUSER

226

DIFFICULTY AND UNFAIRNESS OF ENFORCEMENT

227

DUTY

227

THE OBSCURE BUT LAWFUL PURPOSE

229

ABERRATION

229

8 Causes and Effects

\section{CAUSES}

239

Lawlessness Generally

233

Lieberman's Law

237

Inability to Admit Mistakes

239

Corruption

241

Political Pressure

Stupidity, Insensitivity, and Oversight

243

Mistakes and Ignorance

Lack of Professionalism

Lack of Resources

The Inoperative Personal Belief Syndrome

Crisis

Absurdity of the Laws 
9 Bringing the Government to Account 256

OPENNESS AND SECRECY $\quad 257$

$\begin{array}{ll}\text { PRODDING } & 260\end{array}$

LESS BUREAUCRACY: CONSOLIDATION AND REPEAL 268

MORE BUREAUCRACY: THE OMBUDSMAN AND OTHERS 269

Appendix: The Comptroller General Responds 274

Notes and References $\quad 283$

$\begin{array}{ll}\text { Index } & 299\end{array}$ 


\section{1}

\section{A Healthy Contempt for the Law}

LET'S PUT CRIME in perspective and openly admit that we couldn't get along in America unless we were all willing to break the law. Despite gloomy ruminations over the sorry state of things in this most apocalyptic of centuries, we Americans do remain steadfastly cheerful about at least one thing-the life of crime. That unremitting moralist, Senator Strom Thurmond, spoke for every American when he tongue-lashed a policeman who was dimwitted enough to attempt to arrest him for running a red light. Senator Thurmond did not deny the crime; he merely reminded the officer that a Senator cannot constitutionally be arrested for committing traffic violations when the Senate is in session. "He didn't understand the system," the Senator later complained of the hapless cop.

In pursuing our way of life, Americans generally share Senator Thurmond's healthy contempt for the law (if not always his immunity). When we have wanted to do something that disturbs our moral sense, we have seen to it that a law is put on the books and have then gone right ahead anyway, secure in the knowledge that we have discharged our moral duty. And we all break laws, those of us who decry the breakdown of law and order no less than others.

When morality is on the books, it is accounted for. Fornication and adultery are crimes, but Americans-even law-abiding Americans-are guilty of them nonetheless. There were tens of thousands-maybe mil. lions - of drinkers during Prohibition, but Congress refused to authorize adequate funds to permit the alcoholic ban to be enforced. Drug laws and children aren't what they used to be: if some unlucky individuals are convicted of smoking marijuana, most are not-by mutual con. sent of the police and the governed. Congressmen don't like other people to accept bribes; but they are more equivocal when it comes to 
judging their own behavior, and eager officials in the Justice Department would rather not indict until the candidate has lost. You're a sucker if you think the Internal Revenue Service will spot every bit of padding, and you are not supposed to jaywalk or speed, but everyone does. A free nation of activists need hardly be deterred by restrictions everyone knows were never intended to be enforced. It is the pact we Americans have made with ourselves: condemnation without injunction. So many laws and so little reason to abide by any of them. Even more than baseball or professing self-righteousness, law-breaking is the national pastime.

To be sure, some among us profess disgust with crime. Some even deplore the "crime rate" and its inevitable, drum-rolling increase. Candidates of most persuasions, suburbanites, depraved city dwellers, and even some honest folks have expressed alarm at the rape and robbery index. The Governments of the United States pour out torrents of statistics to show us how worried we should be. But surely many of our esteemed citizens are joking, for they own guns and glorify bad men by paying high prices at movies to be nourished by violent deeds. Surely these protestations of innocence are merely the subtle jokes of a people more sophisticated than most suspect. But perhaps not. For the crime statistics measure only "hard" crime, and the lawbreaking in which most Americans indulge is "soft" or "petty" crime, not usually measured because it is rarely detected. So the irate citizen who takes a few office supplies home for his personal use or pads an expense account is not necessarily inconsistent-and may be innocent in outlook, if not in deed-when he decries the steady increase in larceny.

This "soft" lawbreaking would be inconsequential and scarcely worth noting, except that it establishes a moral climate conducive to a grander form of lawbreaking. Petty thievery is obviously a business expense; speeding, of itself, hurts no one; "nickel-and-dime" cheating on a tax return hardly affects the size or operations of the federal Government. So none of these incidents of lawbreaking causes any general crisis in confidence about America itself. They do, however, provide the foundation for our tolerance of the most serious threat to law and order: "official" lawbreaking by the Government itself.

Nowadays when Presidents of the United States and other officials of high rank-like Kings and Premiers-exhort their citizenry to obey the law, the implication is obvious that the governments they head are virtuous upholders of the law of the land. It is, in fact, more than an implication: every President likes to say that his administration will enforce to the limit all the laws, without fear or favor, equally and without discrimination.

Thus, President Eisenhower at a news conference in 1954 shortly after the Supreme Court ruled public school segregation unconstitutional, 
said: "The Supreme Court has spoken and I am sworn to uphold the constitutional processes in this country; and I will obey." * And President Nixon, similarly asked of his policy with regard to the Supreme Court's decision in 1969 ordering immediate school desegregation, said: "To carry out what the Supreme Court has laid down. I believe in carrying out the law even though [I disagree with the Supreme Court decision]. . . . But we will carry out the law."

It was not always so. Years ago kings were not wont to disguise their conceits: "L'état, c'est moi," said Louis XIV, and no one supposed a public would react to the belief with an overbearing display of moral indignation. Kings were above the law, not of it. Since they made it, they scarcely were required to abide by it. In our time, even Mao Tsetung has proclaimed his empire a "People's Democracy." Though the conceit may be the same, "democracy" has made its claim so strong that few would seriously support another name. It means, no matter how dazzling the rationalization may sometimes be, that governments are creatures of the law.

We should not be fooled by the claim. Unhappily, not all governments today abide by the proposition that the state is subservient to law. In the Soviet Union, for example, it is a commonplace that Russian citizens are subject to a rule of men. Suspects of suspect crimes are locked up on bureaucratic whim, sentenced to long prison terms for abusing the freedoms of speech and press which the Soviet Constitution purports to grant. Secret police monitor the activities of the citizenry. Thirty-five years ago, millions were murdered during bloody purges. Torture was countenanced. Nations were illegally invaded on trumped up charges in the name of threats to security. Some would contend these things happen still in Russia.

Nor is the greatest ideological foe of the United States the only nation to which an accusing finger can be pointed. Brazilians and Greeks and Pakistanis know torture. In Italy, people can be detained in prison without charges for months, on the flimsiest of grounds; Italian law makes American "preventive detention" seem a polite interlude in a civilized proceeding. In China, there is massive slaughter in the name of revolution. In South Africa, people are detained without cause, placed under a house arrest that continues for years without charges ever being preferred, and political prisoners are tortured and some are killed. Through. out the world repressive juntas, cabals, dictatorships, and elites are commonplace.

The orthodox view is that it doesn't happen here. This is not merely the official line; it is the unblushing opinion of sincere citizens through-

- When asked three months later whether he had given any thought to seeking legislation from Congress to back up the Supreme Court decrees mandating integration, President Eisenhower said: "The subject has not even been mentioned to me." 
out the nation that the Government is a doer of good and that our good will should be accorded it.

There are dissenters. Professor Joseph LaPalombara, a political scientist at Yale University, has charged that the foundations of modern America are sunk deeply into crime and corruption. This, he asserts, is not merely true, it is inevitable: corruption is a necessary mechanism in the development of backward societies, our own not excluded, and our AID officials ought to stop feeding pap to local missions about how to organize and manage pure and sincere development programs. He urges our administrators not merely to tolerate but to appreciate the existence of a little hanky-panky. Professor LaPalombara thinks that in twentieth-century America there is still need to blink at a few honest examples of corruption and official crime.

Just as the private citizen must commit crime to get along in this modern world, the argument runs, so the Government can hardly be expected to sit back and obey the laws which some Puritans among us forced into enactment. The double standard is un-American, and therefore the Government must break the law in a thousand ways; it must break the law in as many ways, in fact, as there are reasons to do so.

When a man is fired from his job for telling the truth to Congress about the scandal in his federal office, his boss has broken the law (but other employees have learned a lesson).

When young children are forced into slavery by the wardens of reformatories, no one can doubt the law has been at least politely overlooked (but someone gets free labor).

When a judge increases the sentence of a convicted felon because the criminal wants to appeal his conviction, the Government has broken the law (but it has forestalled troublesome proceedings).

When the police raid your house because they don't like the discussion that is taking place, the Government has broken the law (but it has warned others against quarrelsome conversations).

When the Defense Department forges documents to be given to a Congressional committee, the Government has committed a crime for which ordinary mortals, unloved by Congress, have been sent to jail (but luckily the federal officers cannot be imprisoned, since they were clearly politically motivated).

When the Government decides that some polluters, but not all polluters, ought to be prosecuted, the Government as well as the polluters have violated the law (but the laudable ends are obvious).

When the President of the United States appoints a man constitutionally ineligible to hold a seat on the Supreme Court, and the Senate confirms the nomination, and the man takes that seat, the Government has merely flouted a silly rule in the Constitution.

When a major general is permitted to hold a job that he may not 
legally hold, and a lieutenant is told he has forfeited his commission under similar circumstances, the Government has breached the law (but the general is protected).

When a high Government officer changes official policy to suit the needs of a prized campaign contributor, bribery has occurred (but the official gets re-elected).

When a prosecutor puts into a case evidence he knows to be false, the Government has committed an illegal act (but it has upheld the "rights" of the public).

The President breaks the law when he commits the United States Government to policies not submitted to the Senate for ratification as required by the Constitution (but he thereby gets policies he might not otherwise have got).

When judges declaim from the bench, as they occasionally do, that they know the law is other than they say, they have broken the law in the name of the state (but the conviction is secured, at least temporarily).

When state legislators, knowing that their constitutions require them to apportion their seats in accordance with a scheme that would not suit them politically, do suit themselves by failing to reapportion for more than seventy years, the legislature has engaged in a willful and continuing flouting of law (that unfortunately has led to federal control we all naturally detest).

When the governmental agencies choose to disregard their own regulations, on the theory that if you make them you can break them, they have violated law (but they do not undermine confidence in the administrative process-if no one finds out).

When clusters of governments, agencies, boards, and bureaus choose to weasel around clear policies against discrimination, they have degraded themselves and disgraced principles for which American constitutional law stands (but they do keep the blacks out a few years more).

And when the Government requires soldiers to obey orders that it may well be unlawful to obey, and condemns these soldiers for obeying the same orders when it becomes clear that they were illegal, some think the Government's lawbreaking skirts visible national disaster, whereas it is perfectly clear that the Government is simply trying to uphold freedom in a time of turbulence, if only the people would let it alone, shut up, and forget about it.

Of course, the Government is merely an odd assortment of people paid by the public treasurer. The "Government" in the abstract does not break the law. Men and women do. When ordinary private citizens break the laws against murder or robbery or extortion, we call them "common criminals" or "thugs," depending on their body weight and resemblance to a Nordic ideal of physical beauty. When extraordinary 
private citizens (those with higher salaries or better connections) break the laws against bribery or price-fixing, we tend to call them "corrupt" or "misguided," depending on the number of times they have been divorced and whether we believe in their product.

So with politicians and officials on the take: he who accepts a bribe or a favor or a suspiciously large campaign contribution has been corrupted, and that is too bad, and a little depressing, to be regretted and condemned; but the fault is peculiar to the criminal and should not: reflect on you or me (so long as it is not too widespread a phenomenon; so long, that is, as we don't know about it). Because nothing much hinges on it, the petty corruption of elected and appointed criminals is not new and is rather boring, except around election time when a man can suddenly be simultaneously a despicable hound and a martyr the likes of whom has not been seen since Giordano Bruno was burned at the stake.

Certain people would have us believe, however, that when public officials break the law for and on behalf of the Government, and not on their own account, crimes of a different order and consequence have been committed. It is said that a democratic society can tolerate random lawbreaking by robbers, rapists, murderers, and even self-styled revolutionaries, but that it cannot avoid serious damage, or even survive, in the face of sustained "official" criminal activity. Historically, the argument is nonsense, since the Government has been breaking the law consistently during the past two centuries and we have not collapsed yet. Rhetorically, however, the argument has a certain surface plausibility: Government lawbreaking, our theorists conclude, is fundamental to the ills of society, for nothing can be more conducive to the breakdown of law than the Government's own willful disinclination to obey it.

The full argument runs something like this: when citizens become criminals on their own account the community has a way of rallying around the agents of "justice." There is little resistance to the notion that those who violate most classes of prohibitory laws are to be condemned, and even among those who advocate "civil disobedience" there is a strong undercurrent of belief that those who break the law for higher ends must be prepared to accept the consequences. Socrates's willingness to accept capital punishment is still generally regarded as a moral act of the first magnitude.

When the Government breaks the law, however, the psychological reactions are far more complex. The community is split. No one need defend a criminal, but "our Government" (as opposed to "the bureaucracy") must be sustained and defended; illegal activity, when committed by the Government, quickly becomes fuzzy and political, thus salving the conscience of some, since staunch and "sincere" political beliefs are highly prized. And when the political activity is illegal, it can put even 
the most fair-minded citizen in a terrible dilemma, for he is part of the citizenry that nurtures the Government. Thus, whenever the Government takes some action, part of the populace-whether a larger or smaller part depends on the issue-will automatically support it simply because it is action taken in the name of the Government. The resulting ambivalence of individuals and antagonisms among citizens of different political opinions can tear society apart.

At first blush, the foregoing argument may seem to have intrinsic appeal. Indeed, the logic is inescapable but for one glaring assumption -namely, that the laws are all perfect expressions of social policies to be enforced or carried out. And obviously, this assumption is fallacious. Laws are often wrong, or sloppily worded, unclear, troublesome, or even dangerous.

Look at the laws that are supposed to protect the consumer and the environment. Look at the laws that are supposed to protect us against fraud and highway accidents. Look at the laws that are supposed to give us good public education and medical services. Doctors have apparently found it easy and profitable to rob and cheat under Medicare. Should we expect greater honesty from the Government?

A Government cannot be expected to obey laws that are inconvenient or unsuited to the needs of the times, for what good is governmental power if it cannot be used? If social illness from Government crimes is the price we must pay for law and order, we ought to be willing to bear it. No less than the common man, the Government must have a healthy contempt for the law if it is to govern at all.

That is the composite answer to the argument against government criminality. More ingenious and narrow answers are made whenever

The President of the United States,

The Army,

The Navy,

Other military services,

The Attorney General,

Other Executive officials,

Prosecutors,

Judges,

Congress, and

The police

break the law. They all have their lawyers. This healthy contempt for the laws, without which society would probably collapse from the strain of trying to remember, much less abide by, the entire rulebook, is a subject that scholars and popularizers sorely neglect, except in bits and pieces, now and then. To illuminate this heretofore dark byway of social science and American mores, the following discussion will chart the ways by which the Government comes to grips with the law-and defeats it. 
It is not ordinary to think of the Government as a lawbreaker, though it is quite usual to berate it for stupidity, cowardice, and folly. Yet in modern times, charges against the Government have taken on a new dimension-not mere hardship born of unwisdom, but rank oppression sired by blatant violations of the law. Hear the rollcall: Mylai, the Panthers, Kent and Jackson State, Attica. Scandal that came to light once in a while and merely titillated or mildly shocked is now a torrent rushing forth, and it horrifies.

But back off. The Government is no citizen, though it is run by citizens-and even the citizen is conceded to have the right to disobey certain laws whose complete depravity convince the Supreme Court of their unconstitutionality. The Government is an instrument designed to bring order out of social chaos. Should it be bound by formalistic legalisms? That is the counterargument, but it will not wash.

Proponents of civil disobedience often point to the moral necessity of disobeying particular laws, while adhering to a belief that "the law" or "law" must continue to be respected, even revered. "The rule of law," they say, has a value intrinsically superior to that of any particular law, moral or immoral, wise or unwise. Though they may break a law to protest it, they will suffer the consequences.

Less conservative advocates of civil disobedience contend that it is a prime fallacy to say "that the rule of law has an intrinsic value apart from moral ends." A law student, in a book review lauding a series of radical essays on law, summed up one extreme view when he recommended that the book "top the reading list of all lawyers who think humanity might be more important than the law."

At the other extreme, of course, some people deny there is ever a cause to disobey any law.

The debate is a fundamental one because it concerns the nature of human freedom-if people are free only as they obey their own laws, what must they do about laws that deprive them of freedom or are otherwise unjust? Can we be free without law? Can we be free with unjust laws? The debate continues to rage wherever it is conceded that people are ends in themselves, and not means to other ends.

The argument is altogether different, however, when the question is whether the government must submit to "the rule of law." For the government is surely a means to an end, not an end in itself. Moreover, it is a means created by law and endowed with great power, which, untempered by the charter of its existence, becomes irrational and unreasoning armed might. The government's disavowal of the rule of law -exemplified by its violation of particular laws-is far stronger than the citizen's protest against a particular law: the citizen will be forced to stand the consequences of his act, whether or not he should morally be 
required to do so; the government will rarely be rebuked in ways that count.

This book is devoted to the government's violation of the rule of law. Some examples are of how the government breaks particular laws; others are instances of the government's failure to enforce particular laws. But this is not a book about particular policies; it is not a book about raw injustices; it is not about unwise acts; it is not even about bad or harmful laws, except insofar as they may be unconstitutional. It is not a book about the injustice of racial conditions in the United States (except insofar as they are the reflection of government criminality), nor about the injustice of poverty, war, or inequality; again, except insofar as these conditions spring from the disobedience of government to the rule of law.

Of course, the most clearly seen goal can be thwarted by the awkward fuzziness of reality. "The law" is rarely clear, and therefore, what is unlawful is not always easy to discern. The legal profession has thrived in Western culture for more than five centuries because of that plain fact.

The lack of clarity and certainty in law not only creates confusion for the citizen; it spawns political institutions of vast and ill-defined powers. A government of many and diverse powers and its attendant bureaucracy, created to control the infinite variety of private crimes, undesirable practices, and acts of moral turpitude high and low, carries with it an amazing degree of discretion. Statutes creating administrative agencies are always vague. The laws allow to the administrators, and even their clerks and assistants, a wide latitude of possible moves. If this is an evil to be deplored, it inheres in the nature of things. Regula. tory authority cannot be clear-cut. If the aim is to put an end to discriminatory and shady business practices, a clear definition of what is prohibited would permit any moderately intelligent lawyer to show his client a dozen ways to.avoid the law. So it is said.

Bureaucracies are not the only governmental agencies with the power of discretion. All law confers some degree of discretion. Judges who apply the laws of ordinary crimes, of contracts, and of fiduciary responsibility must be guided by their sense of equity and by their own judg. ment, for these laws talk in terms of "reasonableness" and "substantiality," terms that give those who must judge room in which to wander. Thus, much of what a trial judge decides will not be upset on appeal even though the higher judge thinks it wrong, because the law permits the trial judge the leeway of discretion, and often only clear abuses are reversible.

On final analysis, this is as it has to be. Decisions must be made in life, and people have to know they can rely on what has been decided. 
A course of conduct that calls for a decision to move this way or that cannot forever be held in abeyance because it is subject to being second- and third-guessed. This is true of personal life as well as public life, and mistakes should be tolerated because there is no realistic alternative. The code of law that dispenses with all discretion is and always will be an impossibility.

Unfortunately, this fact stands obstinately in the way of controlling - even judging-both undesirable and unlawful government behavior. If it is imperative to grant the Government discretionary powers, it is correspondingly difficult to block their usage. The result is that the Government takes actions that are immediately denounced by partisans as being unwarranted, unwise, or unlawful.

Legality is a slippery concept. Like most complex abstractions, it is subject to daily abuse. The temptation is often overwhelming to denounce what we despise as not merely wrong, misguided, or evil, but as actually unlawful or even unconstitutional. "They can't do that," we say. The capacity to distrust Government and to be discontented by what it does is nearly infinite; the United States, we like to remind ourselves somewhat mistakenly, was founded on just that distrust and skepticism.

Lack of agreement does not convert otherwise lawful action into crime, however. Though there can be nearly unanimous agreement that some laws are unwise or unjust, it will not wash to describe actions taken pursuant to such laws as illegal. The oil depletion allowance is condemned by many people, conceivably even by a public majority. You can say the allowance is unwise and unjust. Yet deductions taken pursuant to it cannot therefore be regarded as unlawful. Neither can the Government's refusal to grant deferments to those young men who conscientiously object to certain wars be branded as unlawful, though you may deplore the spirit and the reach of the Selective Service Act, which allows draft boards to deny such requests. Even obvious Government oppression is not necessarily illegal, though the dividing line between lawful oppression and unlawful acts is often extremely difficult to discern.

For the most part, governmental actions explored in this book can be tested against the standards of the laws. One agency will give us trouble: the Supreme Court of the United States. For just as a king might be perplexed to know how he could be bound by the law that he fashioned and could unfashion, so it is difficult to contend that the Court can act unlawfully when it interprets the Constitution or other laws. As Justice Robert Jackson once said: "We are not final because we are in. fallible, but we are infallible only because we are final." This is not to say that the Court has not made some outrageous decisions; everyone agrees it has. It is only to say that we will have to proceed with some caution in alleging errors in measurement against the holder of the yardstick. 
Because the Court is likely to change the meaning of the Constitution at unpredictable times, it is sometimes unfair to charge that an official agency has acted unconstitutionally before the Court has so characterized the agency's activities. While the supremacy of the Court's constitutional decisions is unquestioned here, they will for the most part be used to test the legality of governmental action prospectively. To take an obvious case, racial segregation of public educational institutions, while regrettable and oppressive in 1953 and before, was not unlawful in states that had laws permitting it, because the Supreme Court itself had sanctioned the practice in 1896. In 1954, however, after the Supreme Court ruled such practices unconstitutional, further adherence to the policy became blatantly illegal. (There are, however, occasions when it is clear that a Supreme Court decision should be used to test the legality of Government activity retroactively, for the Government frequently acts in ways never judicially sanctioned.)

The test for illegality is not easy to apply, though the extent of governmental illegality is widespread enough to make for easy pickings. Often a law will be clear enough on its face that anyone who denies the violation is saying merely that "no" is "yes," a definitional process that happens more often than it should. More regularly still, owing to the fact that courts must interpret the muddy sentences of legislatures, judicial decisions make it unmistakably clear that the law means that the Government may not do what it commonly does. In response, the Gov: ernment will sometimes simply remain silent. Occasionally, Government will attempt to shift the focus by accusing its accuser of crimes. Most often the Government, caught with its pants down, will attempt to create a haze of justification and block from view those delicate sights sure to cause it and its admirers embarrassment. That the technique of law-avoidance requires the government to assert that what is a crime is not, that it is really just some routine, discretionary, managerial, executive function, ought to fool no one. Painting a leaky ship will not prevent it from sinking, even if those who believe the defect has been remedied stay aboard. 